\title{
Contents, Vol 32, 1992
}

Founded 1897 as 'Monatsschrift fiir Psychiatrie und Neurologie', continued 1957-1967 as 'Psychiatria et Neurologia'

Founders: C. Wernicke and Th. Ziehen.

Successors: K.Bonhoeffer (1912-193 8), J. Klaesi (1939-1967), E.Grtinthal (1953-1967)

\section{Editor-in-Chief}

H.E. Kaeser, Basel

\section{Associate Editors}

C. Loeb, Genova H.P. Ludin, St. Gallen H. vander Eecken, Ghent Editorial Board

\author{
G. Benzi, Pavia \\ J. Bogousslavsky, Lausanne \\ P.J. Dyck, Rochester, Minn. \\ A.G. Engel, Rochester, Minn. \\ R.E. Gonsette, Melsbroek \\ S. Harel, Ramat Gan \\ W. Hartje, Aachen \\ C. Hess, Bern \\ L. Kappos, Basel \\ P. Kleihues, Zurich \\ P. Krauseneck, Wiirzburg \\ Th. Landis, Zurich \\ P.O. Lundberg, Uppsala \\ G.L. Mancardi, Genova
}

O. Meienberg, Binningen

E.W. Radii, Basel

H. Reichmann, Wiirzburg

P. Rondot, Paris

G. Salamon, Marseille

E. Satoyoshi, Tokyo

R. Schiffter, Berlin

G. Scollo-Lavizzari, Basel N. Sorensen, Wiirzburg H.J. Steiger, Bern W. Tackmann, Bonn P.K. Thomas, London A. Valavanis, Zurich

F. Vassella, Bern 
Medical and Scientific Publishers Basel $\bullet$ Freiburg $\bullet$ Paris $\bullet$ London New York $\bullet$ New Delhi $\bullet$ Bangkok Singapore $\bullet$ Tokyo $\bullet$ Sydney

Drug Dosage

The authors and the publisher have exerted every effort to ensure that drug selection and dosage set forth in this text are in accord with current recommendations and practice at the time of publication. However, in view of ongoing research, changes in government regulations, and the constant flow of information relating to drug therapy and drug reactions, the reader is urged to check the package insert for each drug for any change in indications and dosage and for added warnings and precautions. This is particularly important when the recommended agent is a new and/or infrequently employed drus.

No part of this publication may be translated into other languages, reproduced or utilized in any form or by any means, electronic or mechanical, including photocopying, recording, microcopying, or by any information storage and retrieval system, without permission in writing from the publisher or, in the case of photocopying, direct payment of a specified fee to the Copyright Clearance Center (see 'Information for Readers and Subscribers')

(c) Copyright 1992 by S. Karger AG, P.O. Box, CH-4009 Basel (Switzerland) Printed in Switzerland on acid-free paper by Thur AG Offsetdruck, Pratteln

\section{Contents Vol. 32,1992}

No. 1
No. 2

Original Papers

Homocystinuria Presenting as Sagittal Sinus Thrombosis $\quad 1$ Cochran, F.B.; Packman, S.

Influence of Fatty Acid Content of Lysophosphatidyl Choline on Its Myelinotoxic Properties

Sedal, L.; Jennings, K.H.; Allt, G.; Ghabriel, M.N.; Harrison, M.J.G.

Spinal Leptomeningeal Neoplastic Disease. Evaluation by MR, 11 Myelography and CT Myelography Schuknecht, B.; Huber, P.; Buller, B.; Nadjmi, M.

Magnetic Resonance Imaging Findings in Leber's Hereditary 17

Optic Neuropathy

Dotti, M.T.; Caputo, N.; Signorini, E.; Federico, A.

Computed Tomography in the Assessment of Seizure-Induced 20 Supratentorial Neuron Loss Bisgard, C; Fog, I.

Transitory Alexia without Agraphia in an HIIV-Positive Patient 26 Suffering from Toxoplasma Encephalitis: A Case Report Luscher, C; Horber, F.F.

IgG Antibody against GMḷ, $\mathrm{G}_{\mathrm{D}} \mathrm{i}_{\mathrm{b}}$ and Asialo-GMị in Chronic 28

Polyneuropathy following Mycoplasma pneumoniae Infection Yoshino, H.; Inuzuka, T.; Miyatake, T.

Relationship between Levodopa-Independent Symptoms and 32

Central Atrophy Evaluated by Magnetic Resonance Imaging in

Parkinson's Disease

Durif, F.; Pollak, P.; Hommel, M; Ardouin, C; Le Bas, J.F.

Crouzet, G; Perret, J.

Long-Term Results of Corticosteroid Therapy in Patients with 37

Myasthenia Gravis

Evoli, A.; Batocchi, A.P.; Palmisani, M.T.; Lo Monaco, M.; Tonali, P.

Glycyrrhizin (Licorice)-Induced Hypokalemic Myopathy.

Report of 2 Cases and Review of the Literature Shintani, S.; Murase, H.; Tsukagoshi, H.; Shiigai, T.

Prognosis of Transient Global Amnesia: A Long-Term Follow- 52 Up Study

Gandolfo, C; Caponnetto, C; Conti, M.; Dagnino, N.; Del Sette, M; Primavera, A.

Are There Sequential Morphometrical Changes in the Nucleus 58 Basalis in Alzheimer's Disease?

Kobayashi, K.; Miyazu, K.; Nakamura, I.; Fukutani, Y.; Yamaguchi, N.; Nakanishi, I.

Original Papers

TRH Test and the Continuous Dopaminergic Stimulation in 65

Complicated Parkinson's Disease

Lestingi, L.; Bonifati, V.; Stocchi, F.; Antonozzi, I.; Meco, G.

Chronic Histoplasma capsulatum Infection of the Central 70

Nervous System Successfully Treated with Fluconazole Tiraboschi, I.; Casas Parera, I.; Pikielny, R.; Scattini, G.; Micheli, F.

Leptomeningeal Carcinomatosis: A Report of 3 Cases and $\quad 74$

Review of the Literature Gasecki, A.P. Bashir, R.M.; Foley, J.

Study of EEGs following 24-Hour Sleep Deprivation in

Thomaides, T.N.; Kerezoudi, E.P.; Chaudhuri, K.R.; Cheropoulos, C. 
Plasmacellular Angiitis of the Brain-Supplying Arteries with

Disseminated Cerebral Necroses

VoBkamper, M.; Bohm, K.; Hornig, C.R.; Franke, F.; Schachenmayr, W.

Cervical Arachnoidal Cyst with Basilar Impression and

Arnold-Chiari Malformation: A Case Report Fiaschi, A.; Orrico, D.; Polo, A.; Gerosa, M; Bricolo, A.

Magnesium and Calcium Contents in CNS Tissues of Amyo- 95 trophic Lateral Sclerosis Patients from the Kii Peninsula, Japan Yasui, M.; Yase, Y.; Kihira, T.; Adachi, K.; Suzuki, Y.

Subarachnoid and Intramedullary Cysts Secondary to Epidural 99

Anesthesia for Gynecological Surgery

Nogues, M.A.; Merello, M.; Leiguarda, R.; Guevara, J.; Figari, A

Electromyographic Evidence of a Multiple Motor System: $\quad 102$

Implications for Apraxia Lehr, R.P.; Coulson, R.

Cheiro-Oral-Pedal Syndrome

Yasuda, Y.; Morita, T.; Okada, T.; Seko, S.; Akiguchi, I.; Kimura, J.

Thoracic Hematomyelia Secondary to Coumadin Anti-

coagulant Therapy: A Case Report

Constantini, S.; Ashkenazi, E.; Shoshan, Y.; Israel, Z.; Umansky, F.

Botulinum Toxin as a Treatment for Blepharospasm, Spas-

modic Torticollis and Hemifacial Spasm

Albanese, A.; Colosimo, C; Carretta, D.; Dickmann, A.; Bentivoglio, A.R.; Tonali, P.

Facial Pain due to Brainstem Encephalitis. MRI Confirmation 118

of the Lesion

Fukutake, T.; Hattori, T.; Chikama, M.; Kojima, S.; Hirayama, K.

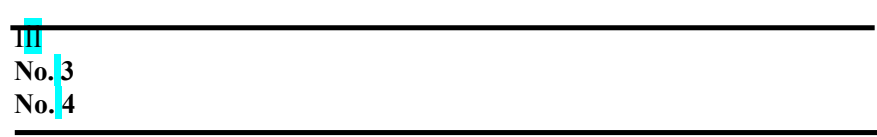

\section{Original Papers}

Clinical, Cytogenetic and Immunological Aspects in 4 Cases 121 Resembling Ataxia Telangiectasia

Lanzi, G.; Balottin, U.; Franciotta, D.; Maserati, E.; Ottolini, A.; Pasquali, F.; Veggiotti, P.

Spinal Cord Sarcoidosis: MRĪ Findings in Response to 126

Treatment

Morita, H.; Hayashi, R.; Tako, K.; Tsukada, N.; Yanagisawa, N.

Myoedema. A Clinical and Electrophysiological Evaluation $\quad 130$

Hornung, K.; Nix, W.A.

Autonomic Dysfunction in Men with Parkinson's Disease

Singer, C; Weiner, W.J.; Sanchez-Ramos, J.R.

Prognosis after Therapy Discontinuation in Children with

Epilepsy

Mastropaolo, C; Tondi, M.; Carboni, F.; Manca, S.; Zoroddu, F.

Paradoxical Enhancement of Hypoperfusion Single Photon

146

Emission CT Images in Epileptic Focus with Bemegride Activation. Observation from Subtraction of ${ }^{99 \mathrm{~m}} \mathrm{TC}$ Hexamethyl-Propyleneamine Oxime Brain Single Photon Emission CT Images Jibiki, I.; Yamaguchi, N.; Matsuda, H.; Hisada, K.

Partially Reversible Parkinsonism in Whipple's Disease with 151

Antibiotherapy

Uldry, P.-A.; Bogousslavsky, J.

Thiamin Contents of Cerebrospinal Fluid, Plasma and

Erythrocytes in Cerebellar Ataxias

Poloni, M.; Mazzarello, P.; Laforenza, U.; Caramella, C; Patrini, C.

About the Mechanism of Hiccup

Askenasy, J.J.M.

Comparison of Magnetic Resonance Imaging in Alzheimer's 164 Disease, Vascular Dementia and Normal Aging Schmidt, R.

Lipid Storage Myopathy in Multiple Acyl-CoA Dehydrogenase 170 Deficiency: An Adult Case

Mongini, T.; Doriguzzi, C; Palmucci, L.; De Francesco, A.; Bet, L.; Manfredi, L.; Ponzetto, C; Bresolin, N.

A Study to Compare Oral Sumatriptan with Oral Aspirin plus 177 Oral Metoclopramide in the Acute Treatment of Migraine The Oral Sumatriptan and Aspirin plus Metoclopramide Comparative Study Group Original Papers

Dystonic Attacks Related to Sleep and Exercise

Montagna, P.; Cirignotta, F.; Giovanardi Rossi, P.; Lugaresi, E. 
Kreuzfelder, E.; Shen, G; Bittorf, M.; Scheiermann, N.; Thraenhart, O.; Seidel, D.; Grosse-Willde, H.

Polymerase Chain Reaction Analysis for Specific HTLV-1 195

Sequences from Cerebrospinal Fluid and Peripheral Blood Cells in Sardinian Multiple Sclerosis Patients Marrosu, M.G.; Mazzoleni, A.P.; Galantuomo, S.; Melis, A.; Muntoni, F.; Lai, E.

Does the Severity of Leukoaraiosis Contribute to Senile 199

Dementia? A Comparative Computerized and Positron Emission Tomographic Study De Reuck, J.; Decoo, D.; Strijckmans, K.; Lemahieu, I.

Diagnosis and Treatment in a Case of Juvenile Subacute

206

Necrotizing Encephalopathy Leigh without Cytochrome c

Oxidase Deficiency

Westarp, M.E.; Holzgraefe, M.; Gallenkamp, U.; Thomas, R.;

Bechinger, D.

Intracranical Aneurysm and Cerebral Embolism

Parenti, G.; Fiori, L.; Marconi, F.

No Re-Expression of High-Affinity Nerve Growth Factor

Binding Sites in Spinal Motor Neurons in Amyotrophic Lateral

Sclerosis

Aquilonius, S.-M.; Askmark, H.; Ebendal, T.; Gillberg, P.-G

Periventricular Plaques in Multiple Sclerosis: Irreversible?

An MRI Follow-Up Study

Baum, K; Nehrig, C; Schorner, W.; Girke, W.

Dorsolateral Pontine Hemorrhage Producing Pure Sensory

Stroke

Deleu, D.; De Waele, J.; Buisseret, T.

Sphenoid Sinus Mucocele with Recurrent Visual Disturbance 225 Yasuda, Y.; Morita, T.; Akiguchi, I.; Kimura, J.; Kameyama, M.

Structural Brain Correlates of Neurourologic Abnormalities in 228 Multiple Sclerosis

Pozzilli, C; Grasso, M.G.; Bastianello, S.; Anzini, A.; Salvetti, M.; Bozzao, L.; Von Heland, M.; Fieschi, C.

Increased Visual Impairment after Exercise (Uhthoff $\mathrm{s} \quad 231$

Phenomenon) in Multiple Sclerosis: Therapeutic Possibilities van Diemen, H.A.M.; van Dongen, M.M.M.M.; Dammers, J.W.H.H.; Polman, C.H.

Acute Measles Encephalitis of the Delayed Type: Neuro-

radiological and Immunological Findings Barthez Carpentier, M.A.; Billard, C; Maheut, J.; Jourdan, M.L.; Degenne, D.; Ruchoux, M.M.; Goudeau, A.; Santini, J.J.

Congenital Basilar Impression: Correlated Neurological

Syndromes

Bassi, P.; Corona, C; Contri, P.; Paiocchi, A.; Loiero, M.; Mangoni, A.

Announcements

IV

\section{Contents}

\section{6th'Symposium on a tong Ferm Ctimicat Care of Parkinson's Disease}

No. 5

Original Papers

Sensory Nerve Abnormalities in Brachial Plexopathy

Rubin, M.; Lange, D.J.

Measurement of Low-Molecular-Weight Antioxidants, Uric 248 Acid, Tyrosine and Tryptophan in Plaques and White Matter from Patients with Multiple Sclerosis Langemann, H.; Kabiersch, A.; Newcombe, J.

Spontaneous Body Sway as a Function of Sex, Age, and Vision: 253

Posturographic Study in 30 Healthy Adults

Kollegger, H.; Baumgartner, C; Wober, C; Oder, W.; Deecke, L.

Intracranial Paramedian Hourglass-Shaped Dermoid Associ- 260 ated with Hereditary Steatocystoma multiplex Nagayama, M.; Shinohara, Y.; Takeoka, T.; Haida, M.; Ikeda, A.; Yamamoto, I.; Sato, O.

Segmental Myoclonus Preceding Herpes zoster Radiculitis

Koppel, B.S.; Daras, M.

Lipoma of the Cauda equina Selectively Involving Lower

Sacral Roots. Case Report Friedli, W.G.; Gratzl, O.; Radii, E.W.

264

267

Superficial Siderosis of the Central Nervous System: Neuro- 270

radiological Evaluation of Two Cases

Daniele, D.; Bracchi, M.; Riva, A.; Duca, S.; Stura, G.; Bradac, GB.

Thermal Thresholds and Motor Sensory Conduction Measure- 274

ments in Guillain Barre Syndrome: 12-Month Follow-Up

Study

Thomaides, T.N.; Kerezoudi, E.P.; Zoukos, Y.; Ray Chaudhuri, K.

Circulating Autoantibody to Muscle Protein in a Patient with 281 Paraneoplastic Myositis and Colon Cancer Ueyama, H.; Kumamoto, T.; Araki, S. 
Focal Involvement and Lateralization in Creutzfeldt-Jakob

289

Disease: Correlation of Clinical, Electroencephalographic and Neuropathological Findings Heye, N.; Cervos-Navarro, J.

Lovastatin/Gemfibrozil Myopathy: A Clinical, Histochemical, 293

and Ultrastructural Study

Chucrallah, A.; De Girolami, U.; Freeman, R.; Federman, M

Herald Facial Numbness 297

Kuntzer, T.; Bogousslavsky, J.; Rilliet, B.; Uldry, P.-A.; de Tribolet, N.; Regli, F.

Relation of Aphemia and Agraphia

Kaminski, H.J.; Adams, N.; Burnstine, T.H.; Civil, R.H.; Ruff, R.L.

Original Papers

Lamotrigine as an Add-On Drug in the Management of

Lennox-Gastaut Syndrome Timmings, P.L.; Richens, A.

Asymptomatic Homozygous Gene Carrier in a Family with

Type I Familial Amyloid Polyneuropathy

Ikeda, S.; Nakano, T.; Yanagisawa, N.; Nakazato, M.; Tsukagoshi, H.

Effect of Brovincamine on Cerebral Circulation and Meta-

bolism in Internal Carotid Artery Occlusion Examined by Positron Emission Tomography Yamaguchi, S.; Fukuyama, H.; Kimura, J.; Yonekura, Y.; Konishi, J.

Parlodel SRO in Parkinson's Disease: A Double-Blind Ran- 318 domized Comparison of Parlodel Standard and Parlodel SRO Jansen, E.N.H.; Staal-Schreinemachers, A.; van der Sande, J.J.; Haas, J.A.; Lakke, J.P.W.F.

Myalgia as the Major Symptom in Systemic Panniculitis

(Weber-Christian Disease) Ohara, S.; Koh, C.-S.; Yanagisawa, N.

Long-Term Influence of Anticonvulsant Agents on Calcitonin, 324

Parathyroid Hormone and Osteocalcin

Rico, H.; Varela de Seijas, E.; Arias, J.A.; Cabranes, J.A

Acute Spinal Epidural Abscess and Spinal Leptomeningitis: 328

Report of 2 Cases with Comparative Neuroradiological and Autopsy Study Fukui, T.; Ichikawa, H.; Kawate, N.; Nozawa, T.; Sugita, K.

Significance of White Matter Lucencies in Posthypoxic-

334

Ischemic Encephalopathy: Comparison of Clinical Status and of Computed and Positron Emission Tomographic Findings De Reuck, J.; Decoo, D.; Vienne, J.; Strijckmans, K.; Lemahieu, I.

Isolated Prolonged Retrograde Amnesia

340

Yoneda, Y.; Yamadori, A.; Mori, E.; Yamashita, H.

Comparative Multiple-Dose Pharmacokinetics of Controlled- 343 Release Levodopa Products

Grahnen, A.; Eckernas, S.-A.; Collin, C; Ling-Andersson, A.; Tiger, G; Nilsson, M.

Intrathecal Immunoglobulin Synthesis in Multiple Sclerosis: 349 Effect of Corticosteroids and Azathioprine Miro, J.; Aguayo, F.; Garrido, J.C.; Alvarez, C; Polo, J.M.; Pascual, J.; Berciano, J.

Orthostatic Tremor Associated with Voice Tremor

354

Yokota, J.; Imai, H.; Seki, K.; Ninomiya, C; Mizuno, Y.

Author Index

Subject Index

\section{Suppl. 1}

6th Symposium on

Long Term Clinical Care of Parkinson's Disease

Tokyo, October 26, 1991 Guest Editor: T. Nakanishi, Tokyo 